\title{
Article \\ Effects of the Use of Different Temperature and Calcium Chloride Treatments during Storage on the Quality of Fresh-Cut "Xuebai" Cauliflowers
}

\author{
Bingyu Mu ${ }^{1}{ }^{\circledR}$, Jianxin Xue ${ }^{1, *}$, Shujuan Zhang ${ }^{1}$ and Zezhen $\mathrm{Li}^{2}$ \\ 1 College of Agricultural Engineering, Shanxi Agricultural University, Jinzhong 030801, China; \\ 13633544838@163.com (B.M.); Z15035658426@163.com (S.Z.) \\ 2 College of Food Science and Engineering, Shanxi Agricultural University, Jinzhong 030801, China; \\ 119834545023@163.com \\ * Correspondence: sxndxjx@sxau.edu.cn; Tel.: +86-133-1344-0069
}

check for

updates

Citation: Mu, B.; Xue, J.; Zhang, S.; Li,

Z. Effects of the Use of Different

Temperature and Calcium Chloride

Treatments during Storage on the

Quality of Fresh-Cut "Xuebai"

Cauliflowers. Foods 2022, 11, 442.

https://doi.org/10.3390/

foods11030442

Academic Editors: Maria Cefola and Bernardo Pace

Received: 5 January 2022

Accepted: 31 January 2022

Published: 2 February 2022

Publisher's Note: MDPI stays neutral with regard to jurisdictional claims in published maps and institutional affiliations.

Copyright: (C) 2022 by the authors. Licensee MDPI, Basel, Switzerland. This article is an open access article distributed under the terms and conditions of the Creative Commons Attribution (CC BY) license (https:// creativecommons.org/licenses/by/ $4.0 /)$.

\begin{abstract}
This study revealed the effect of the use of different temperature and calcium chloride $\left(\mathrm{CaCl}_{2}\right)$ treatments on the storage quality of fresh-cut "Xuebai" cauliflowers. Fresh-cut "Xuebai" cauliflowers were soaked with $2 \% \mathrm{CaCl}_{2}$ solution at different temperatures. The change in the firmness, color, and ascorbic acid (ASA), total glucosinolates (TGLS), polygalacturonase (PG), and lipoxygenase (LOX) content of fresh-cut "Xuebai" cauliflowers during the cold storage period was assessed. In addition, the sensory quality was also evaluated. The results show that the combined treatments with $\mathrm{CaCl}_{2}$ at different temperatures could effectively maintain the storage quality of fresh-cut "Xuebai" cauliflowers. Then, a method based on factor analysis with comprehensive quality evaluation was proposed. A factor analysis with a principal component analysis (PCA) was conducted on nine indicators of cauliflowers. Two principal components were extracted with a cumulative contribution rate of $97.513 \%$. The results demonstrated that the treatment with the best fresh-keeping effect of cauliflowers in storage was the combination treatment at $40{ }^{\circ} \mathrm{C}$ with $2 \% \mathrm{CaCl}_{2}$ solution, while the optimal storage period was 15 days.
\end{abstract}

Keywords: fresh-cut cauliflower; storage period; calcium chloride; temperature; factor analysis; quality

\section{Introduction}

Brassica vegetables are important components of a healthy diet and can help to prevent diseases such as diabetes, cardiovascular disease, and certain cancers; thus, they have attracted the attention of researchers [1-3]. Among cruciferous vegetables, cauliflowers (Brassica oleracea L. botrytis) are important components of human diets and have large economic benefits and yields around the world. The demand for cauliflowers has risen sharply due to their high nutritional value and high levels of many bioactive compounds, including glucosinolates, phenolic compounds, and ascorbic acid [4,5].

Fresh-cut fruits and vegetables are packed and sold after fresh raw materials have been selected, cleaned, peeled, and sliced [6]. Nowadays, with changes in lifestyles and consumption habits, the popularity of fresh-cut cauliflowers has risen among consumers due to their ideal nutritional value, excellent sensory qualities, and health-related benefits for the body [7]. As a basic processing method, cutting will cause browning, odor emission, tissue softening, and a loss of nutritional quality in fresh-cut cauliflower, thus shortening its storage time [8]. As a divalent cation nutrient element, calcium $\left(\mathrm{Ca}^{2+}\right)$ plays a significant role in delaying aging and improving antioxidant capacity in the cell wall and membrane structure. During the cross-linking process between $\mathrm{Ca}^{2+}$ and carboxyl groups in pectin, a structure called "egg box" is formed. This helps to increase the strength of the cell wall and the firmness of the tissue structure [9].

Calcium chloride $\left(\mathrm{CaCl}_{2}\right)$ as a preservative and curing agent has been widely used in the preservation of fresh-cut fruits and vegetables, as it can effectively inhibit the occurrence 
of diseases, inhibit ethylene production, and delay the aging of fruits and vegetables [10,11]. Aghdam et al. (2013) found that postharvest $\mathrm{CaCl}_{2}$ treatment had a positive effect on the antioxidant capacity and DPPH free radical scavenging capacity of cornelian cherry (Cornus mas) fruit. At the same time, the content of active substances such as anthocyanins and ascorbic acid was increased [12]. Zhang et al. (2019) reported that treatment with $2 \%$ $\mathrm{CaCl}_{2}$ could reduce the browning of "Nanguo" pear peel during cold storage, maintain a high hardness and polyphenol content, and inhibit the gene expression of phospholipase D and polyphenol oxidase while reducing their activity [13].

In recent years, heat treatment has attracted researchers' attention because of its advantages in terms of safety, lack of contribution to pollution, and easy means of operation. Through heat treatment, the incidence of chilling injury symptoms in fruits and vegetables can be reduced; the occurrence of respiratory peaks can be delayed; losses of water can be reduced; the ripening, decay and yellowing of fruits and vegetables within the storage period can be controlled; the postharvest quality of fruits and vegetables can be maintained, and their shelf life can be prolonged [14]. As a common method of physical pretreatment for fruits and vegetables, cold treatment can reduce the tissue temperature of fruits and vegetables within a short timeframe, cause them to experience low-temperature stress, induce stress resistance, maintain the balance of active oxygen metabolism in fruits, protect the integrity of the cell membrane structure, reduce enzyme activity, delay fruit aging, and maintain the nutritional quality of fruits and vegetables to the greatest extent possible [15]. Duarte-Sierra et al. (2017) reported that heat treatment can lower the respiratory efficiency of broccoli, maintain a good chemical composition, delay the rate of yellowing of the curd, and lead to a significantly higher content of chlorophyll and glucosinolate than is present in untreated broccoli [16]. Yang et al. (2016) found that $\mathrm{CaCl}_{2}$ treatment can increase glutamine biosynthesis in broccoli, promote myrosinase (MYR) gene expression and activity, and improve the total antioxidant capacity and DPPH scavenging capacity [17]. Grzegorzewska et al. (2009) found that, during the storage period, broccoli treated with ice water had a lower rooting rate, lower loss of tightness, and minor color change [18].

Some research reports have shown that $\mathrm{CaCl}_{2}$ treatment combined with other methods is a good method of fruit and vegetable preservation. Wang et al. (2014) reported that the combined treatment with $\mathrm{CaCl}_{2}$ and cold water at $0{ }^{\circ} \mathrm{C}$ can inhibit the respiration rate of sweet cherries, help them maintain a brighter luster, enhance their antioxidant system, and reduce the peroxidation of membrane lipids. In the end, the authors achieved their goal of reducing the rate of decay of cherry fruit and delaying its senescence speed [19]. Supapvanich et al. (2012) suggested that the use of hot $\mathrm{CaCl}_{2}$ dips at $40{ }^{\circ} \mathrm{C}$ could help to maintain the postharvest quality of fresh-cut sweet leaf bush, delay the decrease in chlorophyll content, delay yellowing, and help to maintain a high nutritional quality, especially with regard to the activities of total phenols, flavonoids, and antioxidant enzymes [20].

Unfortunately, there has been no related exploration of the change in the preservation quality of fresh-cut "Xuebai" cauliflowers through combined treatment with temperature and $\mathrm{CaCl}_{2}$. Therefore, this study aimed to select the optimal temperature of $\mathrm{CaCl}_{2}$ solution for the preservation of fresh-cut "Xuebai" cauliflower florets at $4{ }^{\circ} \mathrm{C}$. The effects of $\mathrm{CaCl}_{2}$ solutions of different temperatures on the color value, firmness, ascorbic acid content (ASA), total glucosinolates content (TGLS), and polygalacturonase (PG) and lipoxygenase (LOX) activities during storage of fresh-cut "Xuebai" cauliflower florets were studied. By measuring multiple indicators, conducting sensory evaluation (SE), combining principal component analysis and factor analysis, and sorting out the scores, the most suitable compound treatment method for fresh-cut "Xuebai" cauliflower preservation was screened. This study provided theoretical support for the research and development of storage and preservation technology for fresh-cut "Xuebai" cauliflower florets and the extension of shelf life. 


\section{Materials and Methods}

\subsection{Plant Material and Treatments}

"Xuebai" cauliflower (Brassica oleracea L. botrytis) was picked in Juxin Agricultural Park (112.49 N and 7.39 E) in Taigu, Shanxi Province of China. After picking, the cauliflower was precooled by vacuum in the field, put into a foam box with small ice cubes, and transported to the laboratory. The selected cauliflower samples were similar in size and without any diseases, insect pests, or mechanical damage. We cut cauliflower into small flower balls (about $50 \mathrm{~g}$ ) of the same size with a knife sterilized in $0.1 \%$ sodium hypochlorite solution, soaked the flower balls in $0.1 \%$ sodium hypochlorite solution for $5 \mathrm{~min}$, rinsed them with sterile water, and took them out to dry.

After drying, 21 samples were separated from the freshly cut florets and analyzed. A total of 420 fresh-cut cauliflower samples were selected and divided into four groups (each with 105 samples); then, the following treatments were performed: (1) $\mathrm{T} 20{ }^{\circ} \mathrm{C}-\mathrm{CaCl}_{2}$ $0 \%$ : immersed in water at $20{ }^{\circ} \mathrm{C}$ for $10 \mathrm{~min}$; (2) $\mathrm{T} 0{ }^{\circ} \mathrm{C}-\mathrm{CaCl}_{2} 2 \%$ : immersed in $2 \% \mathrm{CaCl}_{2}$ solution at $0{ }^{\circ} \mathrm{C}$ for $10 \mathrm{~min}$; (3) $\mathrm{T} 20{ }^{\circ} \mathrm{C}-\mathrm{CaCl}_{2} 2 \%$ : immersed in $2 \% \mathrm{CaCl}_{2}$ solution at $20{ }^{\circ} \mathrm{C}$ for $10 \mathrm{~min}$; (4) $\mathrm{T} 40{ }^{\circ} \mathrm{C}-\mathrm{CaCl}_{2} 2 \%$ : immersed in $2 \% \mathrm{CaCl}_{2}$ solution at $40{ }^{\circ} \mathrm{C}$ for $10 \mathrm{~min}$. Then, the fresh-cut "Xuebai" cauliflower florets were controlled in a drain basket, dried, and put into a $0.04 \mathrm{~mm}$ PE fresh-keeping bag at a constant temperature of $4{ }^{\circ} \mathrm{C}$ and a $90 \%$ constant humidity for 16 days. For each treatment, we randomly selected 21 samples (a total of 84 samples) for repeated experiments at $0,3,6,9,12$, and 15 days. Then, we determined the quality index and performed a sensory evaluation.

According to the research of Grzegorzewska et al. (2009) and Xue et al. (2021), the temperature setting, number of storage days, and $\mathrm{CaCl}_{2}$ solution concentration of this experiment were determined $[18,21]$.

\subsection{Sensory Quality Scores}

After each sampling, a group of volunteers $(n=9)$ consisting of male and female students were asked to evaluate the following sensory attributes: appearance, aroma, flavor, texture, and overall acceptability. These volunteers received professional training before the assessment and agreed on the assessment criteria. The sensory quality scores for cauliflower ranged from one to nine and were calculated using a weighted method. A score of nine meant the sample was excellent (the color was very good, the flower ball organization was tight, the fragrance was good, and it was not decayed); a score of seven meant it was good (the color and luster were good, tissue, the fragrance was light, and less than one twentieth of the flower buds had spots); a score of five was medium (the color and luster were acceptable, the flower balls were slightly soft, the central organization was loose, there was some fragrance, and one-twentieth to one-fifth of the flower buds had spots); a score of three was poor (the color and luster were not good, more than half of the flower balls were wilted, there was a slight peculiar smell, and one-fifth to one-half of the flower buds had spots); a score of one was extremely poor (the color was very bad, most of the bulbs were wilting, there was a rancid smell, and more than half of the flower buds had spots) [22,23].

\subsection{Firmness Measurement}

The firmness of the cauliflower floret was measured by the TMS-PRO food physical property analyzer (FTC, Sterling, VA, USA). The cylinder probe used was P / $2 \mathrm{n}$, the initial speed was $5 \mathrm{~mm} / \mathrm{s}$, the test speed was $1 \mathrm{~mm} / \mathrm{s}$, the retraction speed was $5 \mathrm{~mm} / \mathrm{s}$, the interval between two extrusions was $2 \mathrm{~s}$, the minimum perception force was $0.4 \mathrm{~N}$, and the extrusion depth was $4 \mathrm{~mm}$. The firmness of each sample was measured three times, and the average value was calculated. The maximum firmness value obtained at the first compression was taken as the firmness value of the sample. 


\subsection{Color Measurement}

Referring to the research of Yan et al. (2020), at each sampling time point, the $L^{*}, a^{*}$, and $b^{*}$ values on the surface of the cauliflower florets were measured using a CR-400 color meter (Konica Minolta, Tokyo, Japan) [23]. Three data points were randomly measured at the top bulge of each sample, and the average value was taken as the final result.

\subsection{Ascorbic Acid Content Measurement}

Cauliflower samples with weights of $1 \mathrm{~g}$ were ground and fixed to $50 \mathrm{~mL}$; the content of ascorbic acid (ASA) was determined by titration with 2-6-dichloro-indophenol. When the ASA was completely oxidized, a drop of the dye caused the oxalic acid solution to immediately appear light pink. This change in color was the end point of titration. According to the titration standard of 2-6-dichloro-indophenol solution, the content of ascorbic acid in cauliflower florets can be calculated. The specific operation method used was based on the method of Chen et al. (2018) [24].

\subsection{Total Glucosinolates Measurement}

Based on the principle that total glucosinolates (TGLS) are hydrolyzed into glucose by myrosinase (MYR) in cauliflower, the content of TGLS was determined by spectrophotometry. A standard solution of 3-5 dinitrosalicylic acid and glucose was prepared, and the glucose standard curve was drawn. Two $0.5 \mathrm{~g}$ grinding samples were accurately weighed and placed in $25 \mathrm{~mL}$ calibration tubes, and to each, $0.1 \mathrm{~g}$ of sodium fluoride was added. Then, we added $20 \mathrm{~mL}$ of boiling water to a test tube, heated it immediately until it boiled, and maintained it there for $10 \mathrm{~min}$. In the other test tube, we added $20 \mathrm{~mL}$ of distilled water at $36{ }^{\circ} \mathrm{C}$ and kept it in a water bath at $37^{\circ} \mathrm{C}$ for one hour. The TGLS was hydrolyzed under the action of MYR. Then, we heated the sample to boiling and kept it there for $10 \mathrm{~min}$. We added six drops of neutral lead acetate to each of the two test tubes, distilled water was added until the solution reached a total of $25 \mathrm{~mL}$, and $0.5 \mathrm{~mL}$ of filtrate was used to determine its absorbance.

\subsection{Polygalacturonase Measurement}

The determination of polygalacturonidase (PG) was performed using visible spectrophotometry. The galacturonidase produced by PG hydrolysis reacted with DNS reagent to produce a brownish red substance with a characteristic absorption peak at $540 \mathrm{~nm}$. The pectinase activity was calculated by measuring the change in the absorbance value at $540 \mathrm{~nm}$.

We weighed $0.1 \mathrm{~g}$ of cauliflower, added $1 \mathrm{~mL}$ of extract, ground it in an ice bath, centrifuged it for $10 \mathrm{~min}$ at $4{ }^{\circ} \mathrm{C}$ with sixteen thousand revolutions, diluted the supernatant five times, and followed the steps of the determination instructions (Soleibao Technology Co., Ltd., Beijing, China).

\subsection{Lipoxygenase Measurement}

The presence of lipoxygenase (LOX) was determined by ultraviolet spectrophotometry (Soleibao Technology Co., Ltd., Beijing, China); LOX can catalyze the oxidation of linoleic acid, and the oxidation product had a characteristic absorption peak at $234 \mathrm{~nm}$. The increasing rate of $234 \mathrm{~nm}$ absorbance was measured to calculate the LOX activity.

\subsection{Statistical Analysis}

For this experiment, we adopted a completely random design. A one-way analysis of variance (ANOVA) was performed on the quality indicators. All indicators were repeatedly measured three times (each repetition included 21 samples), and the results were expressed as mean \pm standard deviation (SD). We used the SPSS 17.0 software and Origin 19 software for data analysis and the creation of graphs. 


\section{Results and Discussion}

\subsection{Effect of Different Treatments on the Quality of Fresh-Cut "Xuebai" Cauliflower Florets}

\subsubsection{Volunteer Group Sensory Evaluation}

The most intuitive indicator that describes the quality of cauliflower and reflects its commercial value is sensory evaluation (SE) [25]. It can be seen from Figure 1 that the sensory score of fresh-cut "Xuebai" cauliflower florets declined during the storage period. The sensory score of the control check (CK) was always lower than that of the other treatment groups. It can be seen from Figure 1 that from $0 \mathrm{~d}$ to $6 \mathrm{~d}$, the sensory scores of the four groups of fresh-cut "Xuebai" cauliflower florets did not differ greatly. However, as the storage period grew longer, the decline in the scores of the CK group accelerated. On the 15th day, the CK group had the lowest score. Samples from this group scored only one point, indicating that they had lost their commercial value. These samples received significantly different scores from those of the groups treated with $\mathrm{CaCl}_{2}(p>0.05)$. In general, the effect of the $\mathrm{CaCl}_{2}+40{ }^{\circ} \mathrm{C}$ treatment was slightly better than that of the $\mathrm{CaCl}_{2}$ $+0{ }^{\circ} \mathrm{C}$ and $\mathrm{CaCl}_{2}+20^{\circ} \mathrm{C}$ treatment groups. Our results showed that treatments with $\mathrm{CaCl}_{2}$ can effectively maintain the marketability of cauliflower.

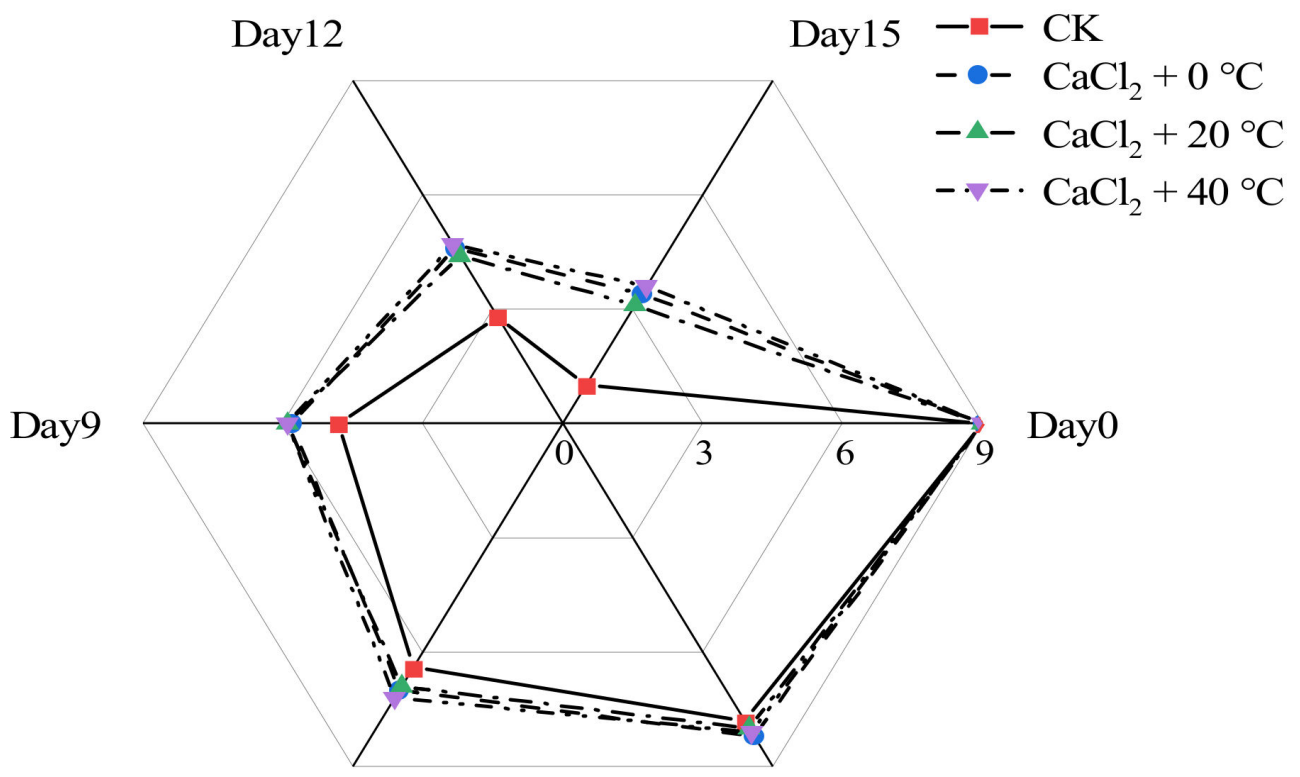

Day6

Day3

Figure 1. Sensory evaluation of fresh-cut "Xuebai" cauliflower florets given different treatments during storage.

\subsubsection{Color}

The color of cauliflower is very important for evaluating its value and quality. However, fresh-cut cauliflower will brown and rot in the postharvest storage process, which is visually manifested as a color change [26]. On the zeroth day of storage, the color values $L^{*}$, $a^{*}$, and $b^{*}$ of fresh-cut "Xuebai" cauliflower florets were $70.265 \pm 0.96,-1.558 \pm 0.67$, and $9.61 \pm 0.35$ in sequence. In Table 1 , the effects of storage time and treatment methods on the lightness $L^{*}$ value (light or dark), $a^{*}$ value (-green to + red), and $b^{*}$ value (-blue to + yellow) are compared. The results show that the lightness of all samples (CK and treated samples) decreased as the storage time grew longer, while the $a^{*}$ and $b^{*}$ values increased over the course of the storage period [27]. 
Table 1. Effects of different treatments on the color of fresh-cut "Xuebai" cauliflower florets.

\begin{tabular}{|c|c|c|c|c|c|c|c|}
\hline \multirow{2}{*}{ Color } & \multirow{2}{*}{ Groups } & \multicolumn{6}{|c|}{ Storage Time/d } \\
\hline & & 0 & 3 & 6 & 9 & 12 & 15 \\
\hline$L^{*}$ & $\begin{array}{c}\mathrm{CK} \\
\mathrm{CaCl}_{2}+0{ }^{\circ} \mathrm{C} \\
\mathrm{CaCl}_{2}+20^{\circ} \mathrm{C} \\
\mathrm{CaCl}_{2}+40^{\circ} \mathrm{C}\end{array}$ & $70.265 \pm 0.96 a$ & $\begin{array}{l}69.207 \pm 0.961 \mathrm{a} \\
69.647 \pm 0.806 \mathrm{a} \\
69.423 \pm 0.612 \mathrm{a} \\
69.873 \pm 0.849 \mathrm{a}\end{array}$ & $\begin{array}{l}67.883 \pm 0.744 a \\
67.810 \pm 0.902 \mathrm{a} \\
68.463 \pm 0.728 \mathrm{a} \\
69.240 \pm 0.731 \mathrm{a}\end{array}$ & $\begin{array}{c}66.127 \pm 0.736 \mathrm{~b} \\
67.510 \pm 0.711 \mathrm{ab} \\
67.290 \pm 0.651 \mathrm{ab} \\
68.360 \pm 0.580 \mathrm{a}\end{array}$ & $\begin{array}{c}63.467 \pm 0.652 \mathrm{c} \\
66.073 \pm 0.347 \mathrm{ab} \\
65.840 \pm 0.517 \mathrm{~b} \\
67.370 \pm 0.723 \mathrm{a}\end{array}$ & $\begin{array}{l}59.923 \pm 0.549 c \\
64.263 \pm 0.346 b \\
63.733 \pm 0.481 b \\
65.700 \pm 0.637 a\end{array}$ \\
\hline$a^{*}$ & $\begin{array}{c}\mathrm{CK} \\
\mathrm{CaCl}_{2}+0^{\circ} \mathrm{C} \\
\mathrm{CaCl}_{2}+20^{\circ} \mathrm{C} \\
\mathrm{CaCl}_{2}+40^{\circ} \mathrm{C}\end{array}$ & $-1.558 \pm 0.67 \mathrm{a}$ & $\begin{array}{l}-1.517 \pm 0.061 \mathrm{a} \\
-1.540 \pm 0.062 \mathrm{a} \\
-1.533 \pm 0.081 \mathrm{a} \\
-1.547 \pm 0.076 \mathrm{a}\end{array}$ & $\begin{array}{l}-1.457 \pm 0.098 \mathrm{a} \\
-1.503 \pm 0.062 \mathrm{a} \\
-1.490 \pm 0.070 \mathrm{a} \\
-1.517 \pm 0.100 \mathrm{a}\end{array}$ & $\begin{array}{l}-1.353 \pm 0.057 \mathrm{a} \\
-1.450 \pm 0.053 \mathrm{a} \\
-1.427 \pm 0.031 \mathrm{a} \\
-1.467 \pm 0.055 \mathrm{~b}\end{array}$ & $\begin{array}{l}-1.187 \pm 0.051 \mathrm{a} \\
-1.357 \pm 0.032 \mathrm{~b} \\
-1.333 \pm 0.091 \mathrm{~b} \\
-1.397 \pm 0.060 \mathrm{~b}\end{array}$ & $\begin{array}{l}-0.987 \pm 0.080 \mathrm{a} \\
-1.283 \pm 0.049 \mathrm{~b} \\
-1.220 \pm 0.123 \mathrm{~b} \\
-1.317 \pm 0.075 \mathrm{~b}\end{array}$ \\
\hline$b^{*}$ & $\begin{array}{c}\mathrm{CK} \\
\mathrm{CaCl}_{2}+0^{\circ} \mathrm{C} \\
\mathrm{CaCl}_{2}+20^{\circ} \mathrm{C} \\
\mathrm{CaCl}_{2}+40^{\circ} \mathrm{C}\end{array}$ & $9.61 \pm 0.35 \mathrm{a}$ & $\begin{array}{l}10.927 \pm 0.787 \mathrm{a} \\
10.433 \pm 0.656 \mathrm{a} \\
10.480 \pm 0.579 \mathrm{a} \\
10.260 \pm 0.321 \mathrm{a}\end{array}$ & $\begin{array}{l}12.877 \pm 0.962 \mathrm{a} \\
11.690 \pm 0.797 \mathrm{a} \\
11.877 \pm 0.670 \mathrm{a} \\
11.470 \pm 0.810 \mathrm{a}\end{array}$ & $\begin{array}{l}14.840 \pm 0.792 \mathrm{a} \\
12.977 \pm 0.290 \mathrm{~b} \\
13.347 \pm 0.696 \mathrm{~b} \\
12.797 \pm 0.597 \mathrm{~b}\end{array}$ & $\begin{array}{l}17.413 \pm 0.751 \mathrm{a} \\
15.393 \pm 0.562 \mathrm{~b} \\
15.277 \pm 0.535 \mathrm{~b} \\
14.547 \pm 0.621 \mathrm{~b}\end{array}$ & $\begin{array}{c}20.317 \pm 0.587 \mathrm{a} \\
16.677 \pm 0.621 \mathrm{bc} \\
17.430 \pm 0.622 \mathrm{~b} \\
16.100 \pm 0.085 \mathrm{c}\end{array}$ \\
\hline
\end{tabular}

Note: Different letters in the same column indicate significant differences at the $p<0.05$ level. $L^{*}$-lightness, $a^{*}$-redness, $b^{*}$-yellowness.

After a prolonged period of storage, the $L^{*}$ values of $\mathrm{CaCl}_{2}$ treated fresh-cut "Xuebai" cauliflower florets were significantly different from those of the CK group on the 12th and 15th day, indicating that $\mathrm{CaCl}_{2}$ can effectively inhibit the browning of fresh-cut "Xuebai" cauliflower florets and decrease the appearance of spots on the flower bud. Throughout the whole storage period, the $L^{*}$ value of fresh-cut "Xuebai" cauliflower florets treated with $\mathrm{CaCl}_{2}+40^{\circ} \mathrm{C}$ was higher than that of the other three groups. On the 15 th day, there were significant differences between cauliflower florets from the $\mathrm{CaCl}_{2}+40{ }^{\circ} \mathrm{C}$ treatment group and those from the other three groups $(p<0.05)$. In addition, the $a^{*}$ and $b^{*}$ values for cauliflower florets given $\mathrm{CaCl}_{2}+40{ }^{\circ} \mathrm{C}$ treatment were the lowest, indicating that $\mathrm{CaCl}_{2}+$ $40{ }^{\circ} \mathrm{C}$ treatment can effectively prevent fresh-cut "Xuebai" cauliflower florets from turning yellow and browning. It can be seen that the $\mathrm{CaCl}_{2}+40{ }^{\circ} \mathrm{C}$ treatment is better able to maintain the quality of fresh-cut "Xuebai" cauliflower florets.

Consistent with our research results, Zhang et al. (2014) [28] found that after heat treatment, the color value of the heat treatment group was better than that of the other treatment groups [28]. Suzuki et al. (2005) reported that heat treatment can reduce the rate of yellowing of cauliflower [29]. Supapvanich et al. (2012) reported that soaking freshly cut beets with hot $\mathrm{CaCl}_{2}$ solution can effectively lower the activity of chlorophylldecomposing enzymes, reduce the loss of chlorophyll and protein in vegetables, delay the loss of greenness, and reduce the rate of yellowing [20].

\subsubsection{Firmness}

In the process of postharvest storage and consumption, firmness is always an important indicator for evaluating the quality of cauliflowers [30]. In this study, the combined treatment with temperature and $\mathrm{CaCl}_{2}$ had a significant effect on the firmness of freshcut "Xuebai" cauliflower florets during their period of storage at $4{ }^{\circ} \mathrm{C}(p<0.05)$. From Figure 2, there was no significant difference between the treatment groups and the CK group throughout the early and middle stages of storage $(p<0.05)$. However, after storage for a longer period of time, the rate of decrease in the firmness of fresh-cut "Xuebai" cauliflower florets given treatment was significantly lower than that of the CK group (12th and 15th days). By the 15th day, there were significant differences between the CK group and the three treatment groups $(p<0.05)$, indicating that the combined treatment was able to maintain the firmness more effectively and reduce the softening of the "Xuebai" cauliflower florets. The difference between the $\mathrm{CaCl}_{2}+0{ }^{\circ} \mathrm{C}$ and $\mathrm{CaCl}_{2}+20^{\circ} \mathrm{C}$ treatment groups was not significant $(p>0.05)$, but the $\mathrm{CaCl}_{2}+40{ }^{\circ} \mathrm{C}$ treatment group showed a significant difference from the other two groups $(p<0.05)$. A comprehensive comparison showed that the $\mathrm{CaCl}_{2}+40{ }^{\circ} \mathrm{C}$ treatment was better able to maintain the firmness of fresh-cut "Xuebai" cauliflower florets. 


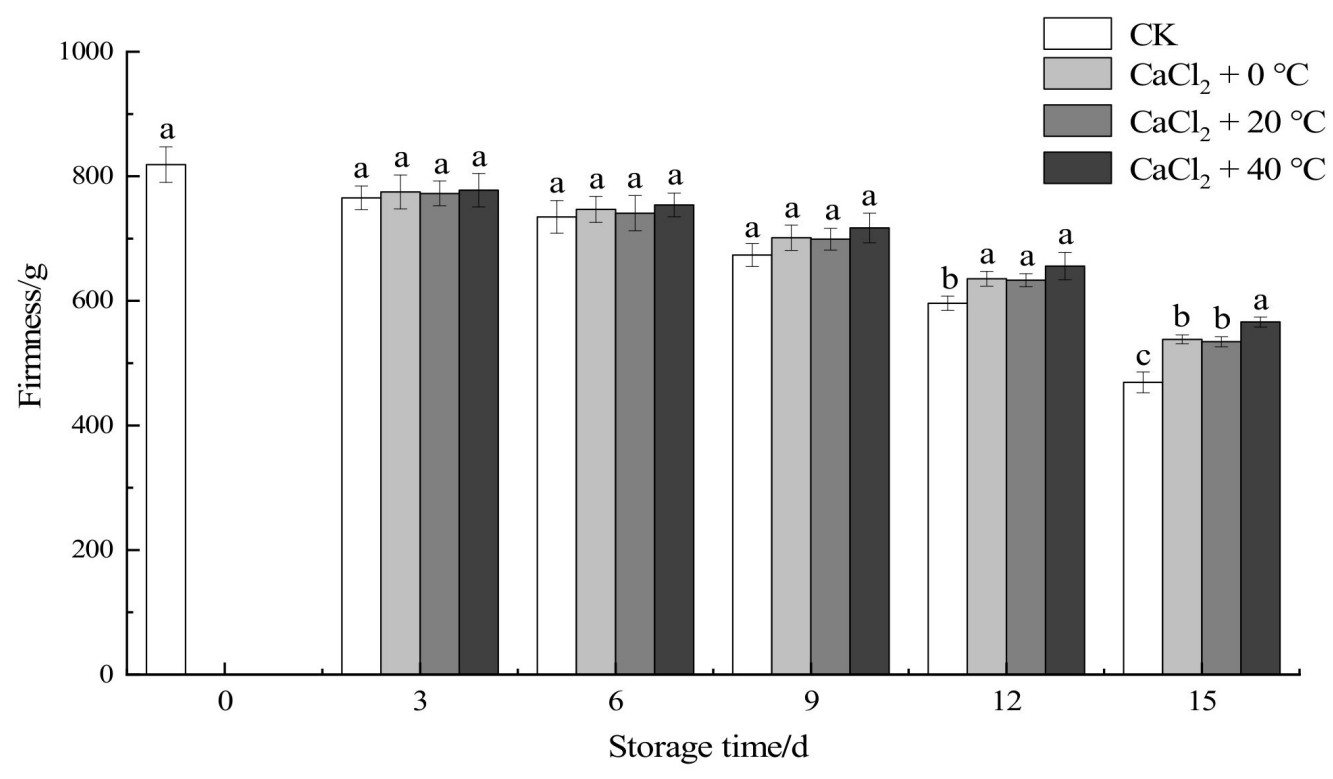

Figure 2. Effect of the different treatments on the firmness of fresh-cut "Xuebai" cauliflower florets. Error bars indicate standard deviation (SD); the statistical significance between the four groups that passed the Tukey significance test is expressed in different lowercase letters, and the significance level is $p<0.05$.

Duarte-Sierra et al. (2017) studied the effect of heat treatment on the quality of broccoli in storage. The results showed that the use of different temperature treatments can lead to the formation of a high initial $\mathrm{CO}_{2}$ content, delay yellowing, maintain a higher level of firmness, and lead to a lower weight loss rate of broccoli [16]. Some enzyme activities relating to hydrolyzing cellulose and pectin increased, dissolving the middle gum layer, loosening the structure of the cell wall, and thus causing the softening of cauliflowers over the storage period [31]. The reason for the rapid decrease in the hardness value was the increase in the rate of metabolism, which is related to aging. Wang et al. (2014) showed that calcium pectate was formed after treatment with $\mathrm{CaCl}_{2}$, which increased the rigidity of the cell wall and reduced the content of PG, pectin methyl esterase (PME), B-galactosidase (b-Gal), etc. These substances are located in the middle layer of the cell wall and are closely related to the activity of enzymes related to fruit softening. In addition, calcium can also fix water and maintain the stability of the pressure between cells, delaying the appearance of softening [19].

\subsubsection{Ascorbic Acid Content}

As shown in Figure 3, with the extension of the storage period of fresh-cut "Xuebai" cauliflower florets, the ASA content in the CK group and treatment groups showed a downward trend. However, the temperature and $\mathrm{CaCl}_{2}$ treatment effectively delayed the decrease in the ASA content. On the 15th day, there was a significant difference between the ASA value of fresh-cut "Xuebai" cauliflower florets given the combined treatments and that of florets in the CK group $(p<0.05)$. Additionally, there was a significant difference between the cauliflowers given the $\mathrm{CaCl}_{2}+40{ }^{\circ} \mathrm{C}$ treatment and those in the other two treatment groups $(p<0.05)$. It can be seen that the $\mathrm{CaCl}_{2}+40{ }^{\circ} \mathrm{C}$ treatment more effectively inhibited the decomposition of ASA during the storage period of fresh-cut "Xuebai" cauliflower florets. 


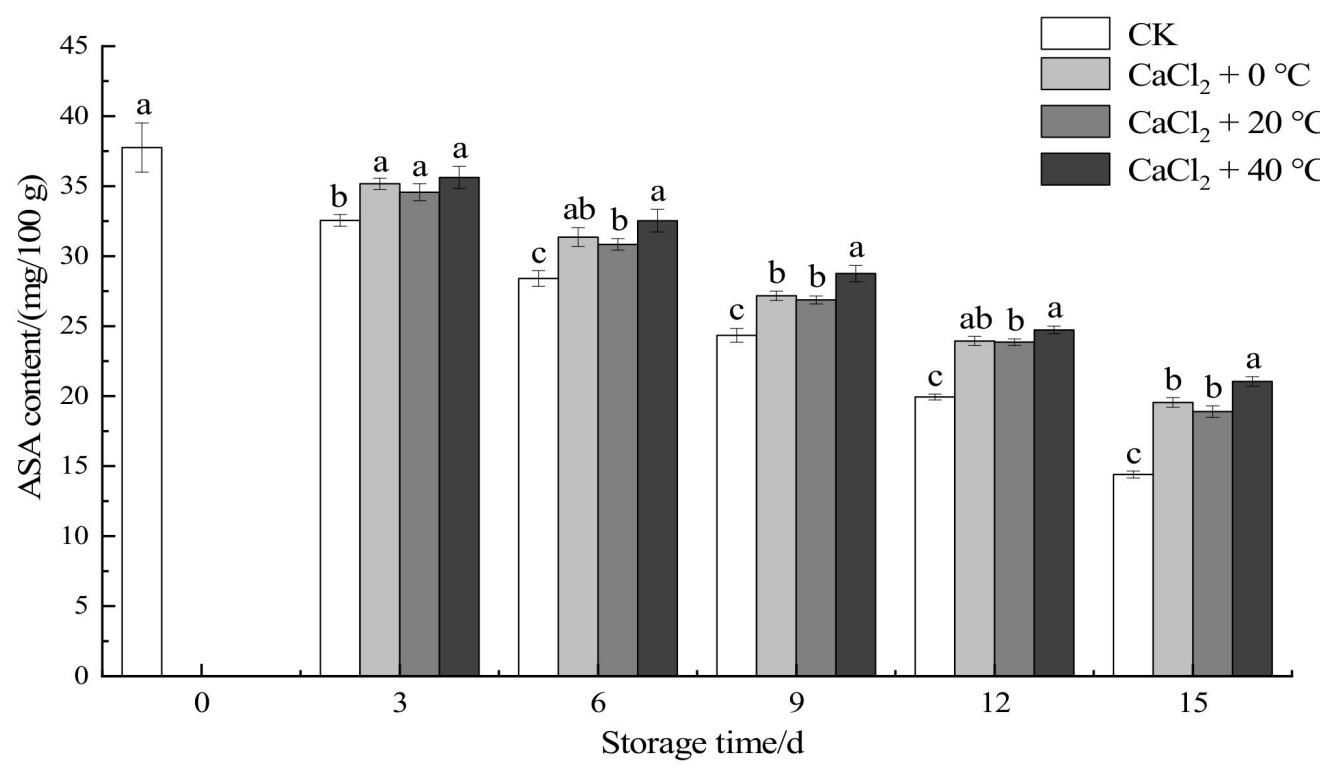

Figure 3. Effect of the different treatments on the ASA content of fresh-cut "Xuebai" cauliflower florets. Error bars indicate standard deviation (SD); the statistical significance between the four groups that passed the Tukey significance test is expressed in different lowercase letters, and the significance level is $p<0.05$.

Many fruits and vegetables are rich in ASA. As is widely known, ascorbic acid is an important antioxidant for the healthy growth of the human body. Ribeiro et al. (2020), in a study on red pomegranate, and Morteza Soleimani Aghdam et al. (2013), in a study on cornelian cherry fruit, reported the positive effect of calcium treatment on delaying the decrease in ASA content [12,32]. Naser et al. (2018), in a study concerning the quality changes in persimmons, showed that the use of a combined calcium and heat treatment can effectively decrease the reduction in ASA. Calcium treatment can act as a signal to activate the antioxidant system inside the cell; calcium treatment can reduce the rate of free radical degradation at the genetic level and reduce the consumption of ASA [33]. Aguayo et al. (2015) reported that heat treatment was used as an auxiliary method to help increase the absorption of ASA in apple tissues. Combined with calcium treatment, it can delay the decrease in ASA content and improve the quality of apples in storage [34].

\subsubsection{Total Glucosinolates Content}

Figure 4 shows that during the storage process, the total glucosinolates (TGLS) content of fresh-cut "Xuebai" cauliflower florets followed a trend of increasing first and then decreasing; these results are the same as those of Wei et al. (2016), Duarte-Sierra et al. (2017), and Xue et al. (2020) [21,35,36]. The TGLS content of the control group was $12.7 \mu \mathrm{mol} / 100 \mathrm{~g}$ on the 9th day, which dropped sharply to $4.2 \mu \mathrm{mol} / 100 \mathrm{~g}$ on the 15 th day. However, the declining trend of the treatment group was not obvious. In the late storage period $(12 \mathrm{~d}$ and $15 \mathrm{~d}$ ), the TGLS content of fresh-cut "Xuebai" cauliflowers in the three treatment groups was higher than that in the CK group, showing a significant difference $(p<0.05)$. Treatment with temperature and $\mathrm{CaCl}_{2}$ can effectively delay the degradation of TGLS in fresh-cut "Xuebai" cauliflower tissues and maintain the good nutritional quality of cauliflowers. The content of TGLS in the group treated with $\mathrm{CaCl}_{2}+40^{\circ} \mathrm{C}$ was the highest. This shows that the effect of the $40^{\circ} \mathrm{C}$ thermal compound treatment was better than that of the $0{ }^{\circ} \mathrm{C}$ and $20{ }^{\circ} \mathrm{C}$ treatments. 


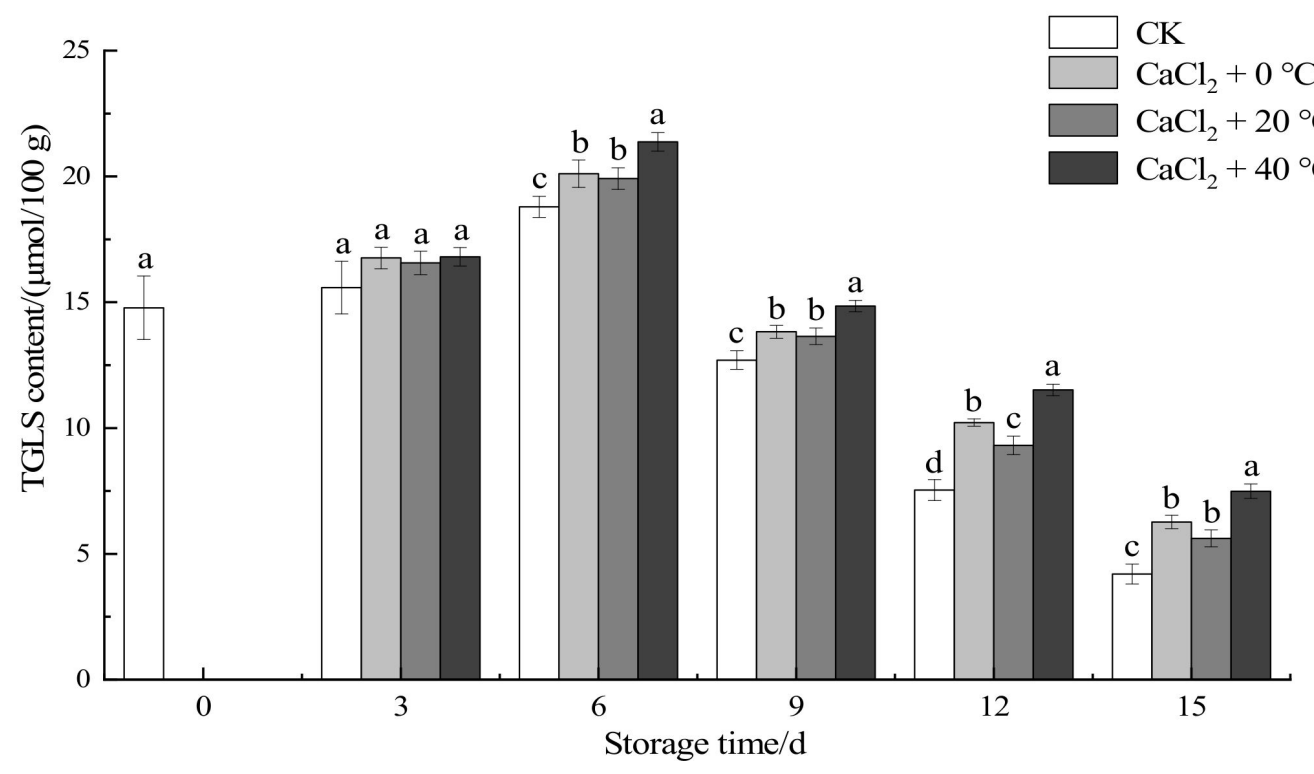

Figure 4. Effect of the different treatments on the TGLS content of fresh-cut "Xuebai" cauliflower florets. Error bars indicate standard deviation (SD); the statistical significance between the four groups that passed the Tukey significance test is expressed in different lowercase letters, and the significance level is $p<0.05$.

Glucosinolates (GLS) are natural biologically active ingredients in broccoli. The endogenous plant enzyme myrosinase in the plant cell, physically segregated from GLS, is released when chopped or chewed to hydrolyze GLS into various products that help prevent cancer, including isothiocyanates (ITCs), thiocyanates, nitriles, and sulforaphane [35]. GLS are distributed in the vacuoles of plants in the form of salts. In the early stages of storage, the increase in GLS due to the presence of hydroxycinnamic acid helps to maintain the rigidity of the cell walls, which can protect plant tissues from damage. However, in later stages of storage, a decrease in TGLS content occurs due to the degradation of GLS [19]. A.P. Vale et al. (2015) reported that the GLS content of broccoli during cold storage increased first and then decreased. The best consumption time was seven days after harvest. During this period of time, the aliphatic GL of broccoli was at a relatively high level. Sulforaphane was the major decomposition product, and it had the effect of reducing the risk of cancer [36]. Heat treatment can significantly improve the retention of glucoraphanin, maintain the quality of broccoli, and extend the shelf life of products [37]. A study on the effect of $\mathrm{CaCl}_{2}$ treatment on the GLS metabolism of broccoli sprouts showed that it promoted the expression of BrST5b (sulfotransferase 5b), inhibited AOP2 (2-oxoglutarate-dependent dioxygenase 2) expression, and induced the expression of genes that synthesize GLS to promote GLS biosynthesis [17].

\subsubsection{Polygalacturonase Activity}

Polygalacturonase (PG) is an enzyme that is closely related to softening senescence, and plays an important role in the degradation of cell wall materials [38]. It can be seen from Figure 5 that, as the storage period grew longer, the activity of PG increased, and the activity of PG in the treatment groups was significantly lower than that in the CK group. There was no significant difference between the treatment groups and the control group in the early stage of the storage period $(p>0.05)$. In the late storage period, the PG activity of the fresh-cut "Xuebai" cauliflower florets in the treatment groups was lower than that in the control group, and there was a significant difference $(p<0.05)$. On the 15th day, the PG activity of the group given the $\mathrm{CaCl}_{2}+40{ }^{\circ} \mathrm{C}$ treatment was 11.99 , which was $23.1 \%$ lower than that of the control group. There was a significant difference in the PG activity between the group given the $\mathrm{CaCl}_{2}+40{ }^{\circ} \mathrm{C}$ treatment and the other two treatment groups. 
The results showed that the treatment with temperature and $\mathrm{CaCl}_{2}$ compound effectively inhibited the activity of PG enzyme during storage and delayed the softening of fresh-cut "Xuebai" cauliflower florets.

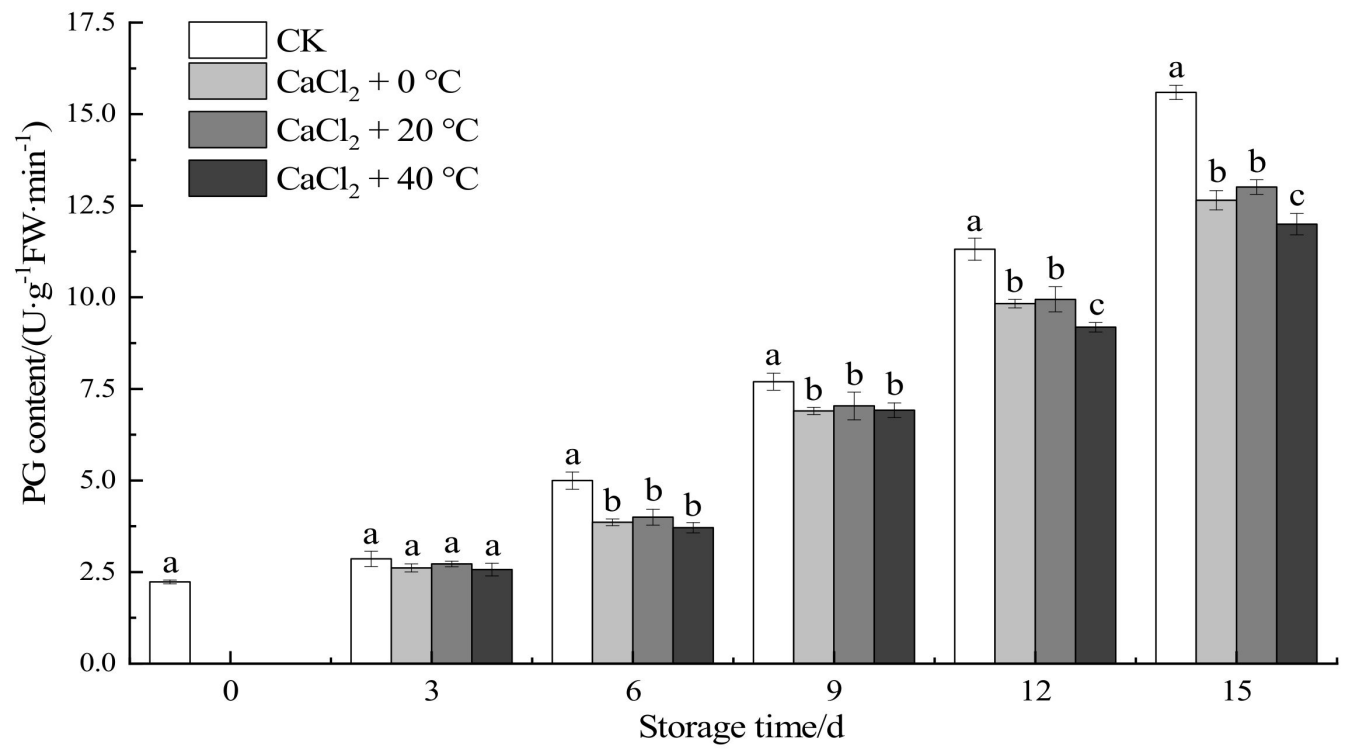

Figure 5. Effect of the different treatments on the PG activity of fresh-cut "Xuebai" cauliflower florets. Error bars indicate standard deviation (SD); the statistical significance between the four groups that passed the Tukey significance test is expressed in different lowercase letters, and the significance level is $p<0.05$.

During the maturation and senescence of fruits and vegetables, the activity of PG, which is a cell-wall-degrading enzyme, increases. As a result, cell wall components such as pectin are degraded, resulting in the softening of the pulp, increased juice yield, and changes in the textural characteristics. During storage, the de-esterification and long-chain depolymerization of pectin occur, leading to the degradations of insoluble pectin into soluble pectin and pectic acid. The adhesion between the cells is reduced, the cell partitions disappear, and the turgor pressure is lost. This causes the cell viscosity and fruit hardness to decrease and finally leads to the softening of the fruit [39]. Ca+ can interact with pectin to form a calciumpectin gel, causing the cell walls to harden and giving them the ability to resist degradation. The use of calcium reduces the accessibility of cell-wall-degrading enzymes [32], thereby causing the activity of PG enzyme to be lower in the treatment group than in the control group. In general, the inhibition achieved by the $\mathrm{CaCl}_{2}+40{ }^{\circ} \mathrm{C}$ treatment was better than that achieved by the other two treatments. We also found that low temperatures do not effectively inhibit the activity of PG enzyme, which is consistent with the results of Tian et al. (2008) [38].

\subsubsection{Lipoxygenase Activity}

Lipoxygenase (LOX) has a peroxidation effect on lipids. It can cause a large number of free radicals to be produced and participate in the synthesis of ethylene, leading to an increase rate of aging in fruits and vegetables [40]. Figure 6 shows that, with the increase in the storage period, the activity of LOX first increased and then decreased, while the LOX value of the treatment groups was lower than that of the CK group. On the third day, there was a significant difference between the fresh-cut "Xuebai" cauliflower florets in the three treatment groups and those in the CK group $(p<0.05)$. On the ninth day, the LOX enzyme activity of the control group and the treatment groups reached a peak, after which the cauliflower began to show rapid softening and worsening effects of aging. By the 15th day, there was a significant difference between the $\mathrm{CaCl}_{2}+40{ }^{\circ} \mathrm{C}$ treatment group and the 
other two treatment groups $(p<0.05)$. It was observed that the $\mathrm{CaCl}_{2}+40{ }^{\circ} \mathrm{C}$ treatment inhibited the LOX activity most significantly.

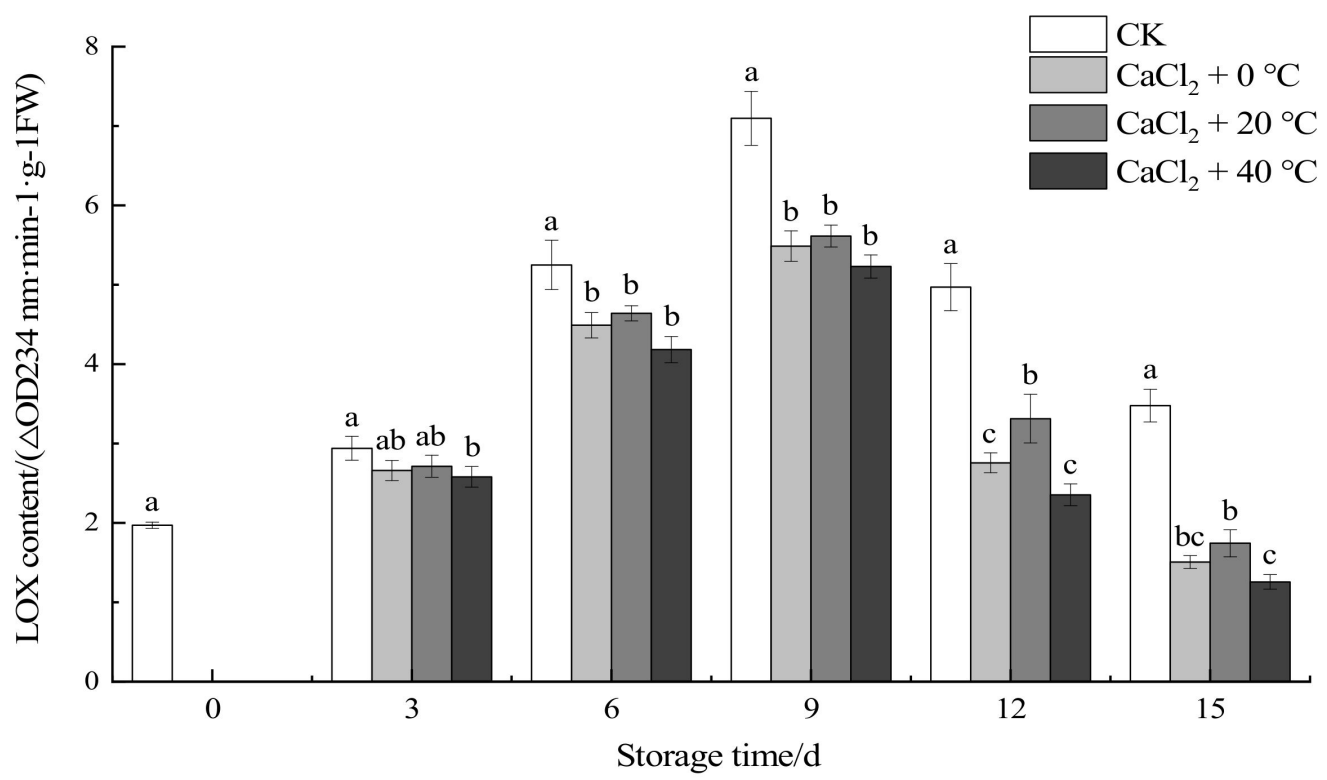

Figure 6. Effect of the different treatments on the LOX activity of fresh-cut "Xuebai" cauliflower florets. Error bars indicate standard deviation (SD); the statistical significance between the four groups that passed the Tukey significance test is expressed in different lowercase letters, and the significance level is $p<0.05$.

LOX can catalyze the oxidative metabolism of unsaturated fatty acids to generate lipid peroxidation free radicals and other substances, activate membrane lipid peroxidation, and aggravate the damage to the membrane structure. The combination of $\mathrm{Ca}+$ and membranes can protect membrane lipids, reduce plant cell membrane damage, and strengthen the cell wall structure. Ca+ plays an important role in stabilizing the membrane lipid structure, preventing membrane damage and maintaining the membrane integrity. However, exposure to low temperatures will induce $\mathrm{Ca}+$ exudation, increase the $\mathrm{Ca}+$ content in the cytoplasmic matrix, increase the activity of lipoxygenase enzymes in the cell, and aggravate the degradation and peroxidation of membrane lipids [41]. These findings are consistent with our conclusion that the $\mathrm{CaCl}_{2}+40{ }^{\circ} \mathrm{C}$ treatment was better than the $\mathrm{CaCl}_{2}+0{ }^{\circ} \mathrm{C}$ treatment in this study.

\subsection{Factor Analysis among Cauliflower Quality Indicators}

We carried out an exploratory factor analysis with dimensionality reduction to extract and synthesize the original variables with overlapping information into a small number of common factors, thereby replacing most of the original variable information. This method was used to model and analyze the quality of fresh-cut "Xuebai" cauliflower florets [42-44].

\subsubsection{Correlation Analysis of Quality Indicators}

During storage, the cell structures of fresh-cut "Xuebai" cauliflower florets were damaged, the permeability of the cell membrane was increased, and the rigidity of the cell wall was decreased. With the degradation of insoluble pectin into soluble pectin and pectic acid, the firmness of fresh-cut "Xuebai" cauliflower florets decreased rapidly and the activity value of the PG enzyme showed an upward trend. However, the ascorbic acid content and $L^{*}$ value both showed downward trends. From the changing trends of the quality indicators of fresh-cut "Xuebai" cauliflower florets, it could be seen that there was an intrinsic connection between them, so it was necessary to carry out relationship research. 
Table 2 shows the results of the relationship analysis carried out on the quality indicators of fresh-cut "Xuebai" cauliflower florets. Very significant positive relationships were observed between the firmness (X1) and $L^{*}$ value (X2), ASA (X5), TGLS (X6), LOX activity (X8), and SE (X9) $(p<0.01)$. Additionally, negative relationships could be clearly observed between the firmness (X1) and $a^{*}$ value (X3), $b^{*}$ value $(X 4)$, and PG activity (X7) $(p<0.01)$. We also observed extremely significant positive relationships between the $L^{*}$ value (X2) and ASA (X5) and TGLS (X6) $(p<0.01)$, as well as an extremely significant negative relationship between the $a^{*}$ value $(\mathrm{X} 3)(p<0.01)$ and PG $(\mathrm{X} 7)(p<0.05)$. The $a^{*}$ value (X3) had very significant positive relationships with the $b^{*}$ value (X4) and PG activity (X7) $(p<0.01)$. There was also a clear negative relationship between the $a^{*}$ value $(X 3)$ and ASA (X5), TGLS (X6), LOX activity (X8), and SE (X9) $(p<0.01)$. The $b^{*}$ value (X4) was extremely negatively associated with the ASA (X5) and TGLS content $(X 6)(p<0.01)$, and significantly negatively associated with the LOX activity $(X 8)(p<0.05)$. The content of ASA (X5) had a very significant positive relationship with the LOX activity (X8) and SE (X9) $(p<0.01)$. The content of TGLS (X6) had very significant positive relationships with the LOX activity (X8) and SE (X9) $(p<0.01)$. There were also very significant negative relationships between the PG activity (X7) and LOX activity (X8) and SE (X9) $(p<0.01)$.

Table 2. Relationship analysis of the quality indicators of fresh-cut "Xuebai" cauliflower florets during storage.

\begin{tabular}{|c|c|c|c|c|c|c|c|c|c|}
\hline & Firmness & $L^{*}(\mathrm{X} 2)$ & $a^{*}(\mathrm{X} 3)$ & $b *(X 4)$ & ASA (X5) & TGLS (X6) & PG (X7) & LOX (X8) & SE (X9) \\
\hline $\begin{array}{c}\text { Firmness } \\
(\mathrm{X} 1)\end{array}$ & 1.000 & & & & & & & & \\
\hline$L^{*}(X 2)$ & $0.957^{* *}$ & 1.000 & & & & & & & \\
\hline$a^{*}(\mathrm{X} 3)$ & $-0.949^{* *}$ & $-0.995^{* *}$ & 1.000 & & & & & & \\
\hline$b^{*}(\mathrm{X} 4)$ & $-0.976^{* *}$ & -0.981 & $0.978^{* *}$ & 1.000 & & & & & \\
\hline ASA (X5) & $0.973^{* *}$ & $0.961^{* *}$ & $-0.950^{* *}$ & $-0.991^{* *}$ & 1.000 & & & & \\
\hline TGLS (X6) & $0.930^{* *}$ & $0.880^{* *}$ & $-0.877^{* *}$ & $-0.900^{* *}$ & 0.899 & 1.000 & & & \\
\hline PG (X7) & $-0.988^{* *}$ & $-0.943 *$ & $0.936^{* *}$ & 0.981 & -0.985 & -0.935 & 1.000 & & \\
\hline LOX (X8) & $0.316^{* *}$ & 0.120 & $-0.131^{* *}$ & $-0.148^{*}$ & $0.130^{* *}$ & $0.381^{* *}$ & $-0.251^{* *}$ & 1.000 & \\
\hline SE (X9) & $0.972^{* *}$ & 0.968 & $-0.965^{* *}$ & -0.995 & $0.993^{* *}$ & $0.899 * *$ & $-0.986^{* *}$ & 0.125 & 1.000 \\
\hline
\end{tabular}

From Table 2, it can be seen that the correlations between the quality indicators of fresh-cut "Xuebai" cauliflower florets were relatively high. However, if a quality assessment is carried out directly, there will be deviations in the assessment results due to the presence of overlapping information [45]. Thus, a factor analysis was conducted to combine several relevant indicators with uncorrelated indicators [44]. This new set of quality indicators was used for the quality synthesis of fresh-cut "Xuebai" cauliflower florets treated with different temperatures and $\mathrm{CaCl}_{2}$ in order to improve the reliability of the evaluation model.

\subsubsection{Principal Component Analysis (PCA)}

The raw data of various indexes of fresh-cut "Xuebai" cauliflower florets treated with different temperatures and $\mathrm{CaCl}_{2}$ were statistically analyzed using the Kaiser-Meyer-Olkin (KMO) and Bartlett test methods. It can be seen from Table 3 that the KMO value was 0.794, indicating that the sampling adequacy effect was very good. The significant difference of Bartlett's spheroid test was less than 0.01; this showed that the quality index data of fresh-cut "Xuebai" cauliflower florets were different. We continued to study these data with a factor analysis. 
Table 3. KMO and Bartlett's correlation test.

\begin{tabular}{ccccc}
\hline \multirow{2}{*}{ Test Method } & \multirow{2}{*}{ KMO Measure of } & \multicolumn{3}{c}{ Bartlett's Test of Sphericity } \\
\cline { 3 - 5 } & Sampling Adequacy & Approx. x2 & df & Sig. \\
\hline Result & 0.794 & 477.288 & 36 & 0.000 \\
\hline
\end{tabular}

A principal component analysis (PCA) was carried out in the SPSS 17.0 software to extract feature values from the quality index data of fresh-cut "Xuebai" cauliflower florets and perform a factor analysis. Table 4 shows that the variances of the common factors of all indexes of fresh-cut "Xuebai" cauliflower florets were above 0.917. This indicated that the effect of the factors analysis was good, and that the quality index data of fresh-cut "Xuebai" cauliflower florets were suitable for factor analysis.

Table 4. Factor variance statistics of quality indicators.

\begin{tabular}{ccc}
\hline Quality Indexes & Initial & Extraction \\
\hline Firmness $(X 1)$ & 1.000 & 0.989 \\
$L^{*}(\mathrm{X} 2)$ & 1.000 & 0.969 \\
$a^{*}(\mathrm{X} 3)$ & 1.000 & 0.959 \\
$b^{*}(\mathrm{X} 4)$ & 1.000 & 0.994 \\
ASA $($ X5) & 1.000 & 0.983 \\
TGLS(X6) & 1.000 & 0.917 \\
PG(X7) & 1.000 & 0.981 \\
LOX(X8) & 1.000 & 0.993 \\
SE(X9) & 1.000 & 0.991 \\
\hline
\end{tabular}

$L^{*}$-lightness, $a^{*}$-redness, $b^{*}$-yellowness.

The PCA and the quarter rotation method were used to obtain the eigenvalues and rates of contribution of each factor of fresh-cut "Xuebai" cauliflower florets; the results are shown in Table 5.

Table 5. Factor analysis of principal component characteristic values and contributions in fresh-cut "Xuebai" cauliflower florets.

\begin{tabular}{|c|c|c|c|c|c|c|c|c|c|}
\hline \multirow{2}{*}{ Component } & \multicolumn{3}{|c|}{ Initial Eigenvalues } & \multicolumn{3}{|c|}{$\begin{array}{c}\text { Extraction Sums of Squared } \\
\text { Loadings }\end{array}$} & \multicolumn{3}{|c|}{ Rotation Sums of Squared Loadings } \\
\hline & Total & $\begin{array}{c}\% \text { of } \\
\text { Variance }\end{array}$ & Cumulative & Total & $\begin{array}{c}\% \text { of } \\
\text { Variance }\end{array}$ & Cumulative & Total & $\begin{array}{c}\% \text { of } \\
\text { Variance }\end{array}$ & Cumulative \\
\hline 1 & 7.736 & 85.960 & 84.960 & 7.736 & 85.960 & 84.960 & 7.717 & 85.744 & 85.744 \\
\hline 2 & 1.040 & 11.553 & 97.513 & 1.040 & 11.553 & 97.513 & 1.059 & 11.768 & 97.513 \\
\hline 3 & 0.113 & 1.261 & 98.773 & & & & & & \\
\hline 4 & 0.085 & 0.949 & 99.722 & & & & & & \\
\hline 5 & 0.013 & 0.141 & 99.863 & & & & & & \\
\hline 6 & 0.008 & 0.086 & 99.949 & & & & & & \\
\hline 7 & 0.002 & 0.025 & 99.974 & & & & & & \\
\hline 8 & 0.002 & 0.017 & 99.991 & & & & & & \\
\hline 9 & 0.001 & 0.009 & 100.000 & & & & & & \\
\hline
\end{tabular}

Table 5 shows the variance contribution rate obtained in the factor analysis of fresh-cut "Xuebai" cauliflower florets. The contribution rates of factor one and factor two to the total variance of fresh-cut "Xuebai" cauliflower floret reached $85.744 \%$ and $11.768 \%$, respectively, while the cumulative variance contribution rate reached $97.513 \%$. Nearly $100 \%$ of the information in the original dataset was covered by these two principal components, so it was determined that the number of factors in the subsequent factor analysis should be two.

Figure 7 shows a schematic diagram of the factor rotation of the correlation coefficients of the nine original indicators and factor one and factor two. It can be seen from Figure 7 
that firmness, TGLS, ASA, $L^{*}$ value, and SE had higher loads in the positive direction of factor one, while PG, $a^{*}$ value, and $b^{*}$ value had higher loads in the negative direction of factor one, which is in line with the actual meaning of each index. It was found that the higher the PG activity, $a^{*}$ value, and $b^{*}$ value were, the more significant the deterioration in the quality of fresh-cut "Xuebai" cauliflower florets was. Additionally, the higher the firmness, TGLS, ASA, $L^{*}$ value, and SE were, the higher the quality of fresh-cut "Xuebai" cauliflower florets was. It can be inferred that factor one comprehensively reflected the main quality indicators, while factor two had a significant positive correlation with the LOX content. This mainly demonstrates the influence of LOX on the storage quality of fresh-cut "Xuebai" cauliflower florets, and its cumulative variance contribution rate was only $11.768 \%$. The impact of this factor on the overall quality was far less important than that of factor one.

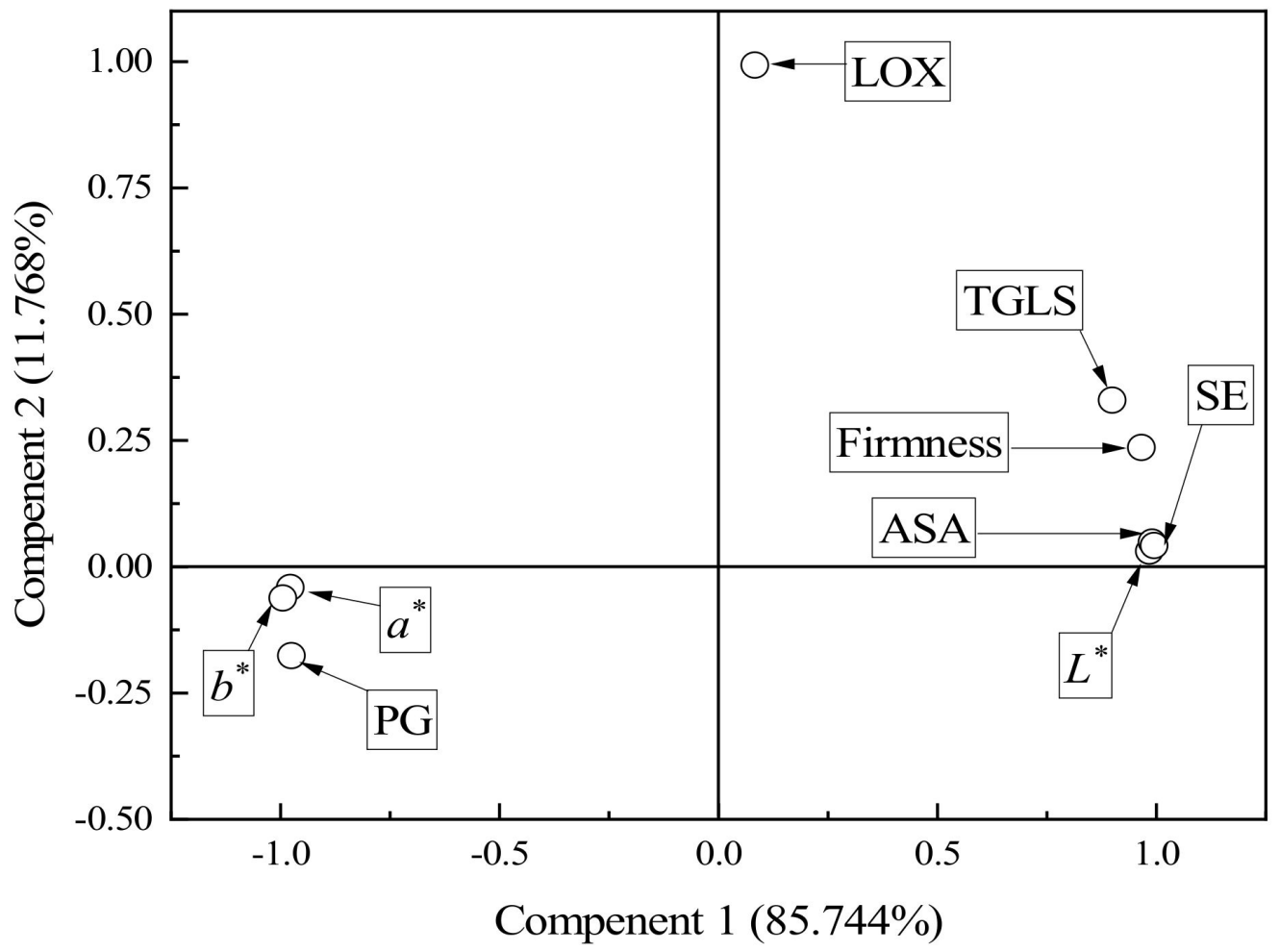

Figure 7. Principal component graph in rotating space. $L^{*}$-lightness, $a^{*}$-redness, $b^{*}$-yellowness.

Table 6 shows the effectiveness of the use of the regression coefficient method to explore the mutual effect of fresh-cut "Xuebai" cauliflower floret quality indicators under $\mathrm{CaCl}_{2}$ treatments at different temperatures. After the data were rotated using the maximum variance method, the expressions of factor one and factor two were obtained.

$\mathrm{Y} 1=0.123 \times \mathrm{X} 1+0.132 \times \mathrm{X} 2-0.131 \times \mathrm{X} 3-0.133 \times \mathrm{X} 4+0.133 \times \mathrm{X} 5+0.111 \times \mathrm{X} 6-0.126 \times \mathrm{X} 7-0.020 \times \mathrm{X} 8+0.133 \times \mathrm{X} 9$

$\mathrm{Y} 2=0.091 \times \mathrm{X} 1-0.106 \times \mathrm{X} 2+0.096 \times \mathrm{X} 3+0.079 \times \mathrm{X} 4-0.090 \times \mathrm{X} 5+0.189 \times \mathrm{X} 6-0.032 \times \mathrm{X} 7+0.933 \times \mathrm{X} 8-0.098 \times \mathrm{X} 9$ 
Table 6. Quality component coefficient matrix of fresh-cut "Xuebai" cauliflower florets.

\begin{tabular}{ccc}
\hline \multirow{2}{*}{ Quality indexes } & \multicolumn{2}{c}{ Component } \\
\cline { 2 - 3 } & $\mathbf{1}$ & $\mathbf{2}$ \\
\hline Firmness (X1) & 0.123 & 0.091 \\
$L^{*}(\mathrm{X} 2)$ & 0.132 & -0.106 \\
$a^{*}(\mathrm{X3})$ & -0.131 & 0.096 \\
$b^{*}(\mathrm{X} 4)$ & -0.133 & 0.079 \\
ASA (X5) & 0.133 & -0.090 \\
TGLS (X6) & 0.111 & 0.189 \\
PG (X7) & -0.126 & -0.032 \\
LOX (X8) & -0.020 & 0.933 \\
SE (X9) & 0.133 & -0.098 \\
\hline
\end{tabular}

$L^{*}$-lightness, $a^{*}$-redness, $b^{*}$-yellowness.

These two common factors reflected the effects of different treatments on the storage quality of fresh-cut "Xuebai" cauliflower florets in terms of different aspects. Then, the variance contribution rate corresponding to each common factor was weighted to obtain the following comprehensive score calculation Equation Y:

$\mathrm{Y}=(85.744 \times \mathrm{Y} 1+11.768 \times \mathrm{Y} 2) \div 97.513=0.119 \times \mathrm{X} 1+0.103 \times \mathrm{X} 2-0.104 \times \mathrm{X} 3$
$-0.107 \times \mathrm{X} 4+0.106 \times \mathrm{X} 5+0.120 \times \mathrm{X} 6-0.115 \times \mathrm{X} 7+0.095 \times \mathrm{X} 8+0.105 \times \mathrm{X} 9$

We normalized the original data and substituted them into Equation Y. Table 7 lists the order of the comprehensive quality index values of fresh-cut "Xuebai" cauliflower florets treated with different temperatures and $\mathrm{CaCl}_{2}$.

Table 7. Ranking of the comprehensive quality index values of fresh-cut "Xuebai" cauliflower florets treated with different temperatures and $\mathrm{CaCl}_{2}$.

\begin{tabular}{cccc}
\hline Method & Storage Time/d & Value & Rank \\
\hline & 3 & 103.285 & 4 \\
$\mathrm{CK}$ & 6 & 99.066 & 8 \\
& 9 & 89.918 & 12 \\
& 12 & 78.230 & 16 \\
& 15 & 60.603 & 20 \\
\hline $\mathrm{CaCl}_{2}+0^{\circ} \mathrm{C}$ & 3 & 104.983 & 2 \\
& 6 & 101.324 & 6 \\
& 9 & 94.059 & 10 \\
$\mathrm{CaCl}_{2}+20^{\circ} \mathrm{C}$ & 12 & 84.302 & 14 \\
& 15 & 70.889 & 18 \\
\hline & 3 & 104.545 & 3 \\
& 6 & 100.455 & 7 \\
& 9 & 93.628 & 11 \\
$\mathrm{CaCl}_{2}+40^{\circ} \mathrm{C}$ & 12 & 83.878 & 15 \\
& 15 & 70.091 & 1 \\
& 3 & 105.410 & 5 \\
& 6 & 102.522 & 9 \\
& 9 & 96.307 & 13 \\
\hline
\end{tabular}

It can be seen from the comprehensive score comparison of $\mathrm{CaCl}_{2}$ treatments at different temperatures in Table 7 that the storage period of fresh-cut "Xuebai" cauliflower florets could be significantly prolonged after treatment with temperature and $\mathrm{CaCl}_{2}$. The fresh-cut "Xuebai" cauliflower florets had the highest score after being treated with $\mathrm{CaCl}_{2}+$ $40{ }^{\circ} \mathrm{C}$, but as the storage time grew longer, their quality continued to decline. After 15 days 
of storage, the comprehensive quality score of the cauliflowers fell below the pass line and the curd softened and browned, causing then to lose their storage value.

\section{Conclusions}

This experiment studied the effect of the use of different temperatures and $\mathrm{CaCl}_{2}$ treatments on the preservation of fresh-cut "Xuebai" cauliflower florets. Through a comprehensive evaluation of our factor analysis, the optimal processing method for cauliflowers subjected to a storage period was determined. The test results showed that as the storage period grew longer, the fresh-cut "Xuebai" cauliflower florets developed a peculiar smell; darkened and yellowed in color; exhibited decreased hardness; decreased SE, ASA, and TGLS content, and showed increased PG and LOX activities. The quality of cauliflowers in the treatment groups was significantly better than that of the cauliflowers in the CK group, and they maintained a higher firmness value, higher ASA and TGLS content, and a lower activity of related enzymes. The factor analysis of indicators of fresh-cut "Xuebai" cauliflower florets during the storage period found that the rate of contribution of the first two principal component factors was $97.513 \%$. These two factors were able to represent the change in the cauliflowers' quality. We also established a comprehensive evaluation model for fresh-cut "Xuebai" cauliflowers. The $\mathrm{CaCl}_{2}+40{ }^{\circ} \mathrm{C}$ treatment was determined to be the best preservation method for fresh-cut "Xuebai" cauliflower florets. This study provides a theoretical reference for extending the storage time of fresh-cut "Xuebai" cauliflower florets and improving their quality during storage.

Author Contributions: Conceptualization, B.M.; methodology, B.M.; data curation, B.M.; writingoriginal draft preparation, B.M.; writing—review and editing, B.M.; supervision, S.Z. and Z.L.; project administration, J.X. All authors have read and agreed to the published version of the manuscript.

Funding: This research was funded by the National Natural Science Foundation of China, Grant/Award Number: 31801632.

Institutional Review Board Statement: Not applicable.

Informed Consent Statement: Not applicable.

Data Availability Statement: Not applicable.

Conflicts of Interest: The authors declare no conflict of interest.

\section{References}

1. Dos Reis, L.C.; de Oliveira, V.R.; Hagen, M.E.K.; Jablonski, A.; Flôres, S.H.; de Oliveira Rios, A. Effect of cooking on the concentration of bioactive compounds in broccoli (Brassica oleracea var. Avenger) and cauliflower (Brassica oleracea var. Alphina F1) grown in an organic system. Food Chem. 2015, 172, 770-777. [CrossRef] [PubMed]

2. Kapusta-Duch, J.; Szelag-Sikora, A.; Sikora, J.; Niemiec, M.; Gródek-Szostak, Z.; Kuboń, M.; Leszczynska, T.; Borczak, B. Health-Promoting Properties of Fresh and Processed Purple Cauliflower. Sustainability 2019, 11, 4008. [CrossRef]

3. Samec, D.; Urlic, B.; Salopek-Sondi, B. Kale (Brassica oleracea var. acephala) as a superfood: Review of the scientific evidence behind the statement. Crit. Rev. Food Sci. Nutr. 2019, 59, 2411-2422. [CrossRef] [PubMed]

4. Avato, P.; Argentieri, M.P. Brassicaceae: A rich source of health improving phytochemicals. Phytochem. Rev. 2015, 14, 1019-1033. [CrossRef]

5. Garcia-Ibanez, P.; Nicolas-Espinosa, J.; Carvajal, M. Plasma membrane vesicles from cauliflower meristematic tissue and their role in water passage. BMC Plant Biol. 2021, 21, 30. [CrossRef] [PubMed]

6. Zhang, H.; Yamamoto, E.; Murphy, J.; Locas, A. Microbiological safety of ready-to-eat fresh-cut fruits and vegetables sold on the Canadian retail market. Int. J. Food Microbiol. 2020, 335, 108855. [CrossRef] [PubMed]

7. Yousuf, B.; Qadri, O.S.; Srivastava, A.K. Recent developments in shelf-life extension of fresh-cut fruits and vegetables by application of different edible coatings: A review. LWT Food Sci. Technol. 2018, 89, 198-209. [CrossRef]

8. Ma, L.; Zhang, M.; Bhandari, B.; Gao, Z.X. Recent developments in novel shelf life extension technologies of fresh-cut fruits and vegetables. Trends Food Sci. Technol. 2017, 64, 23-38. [CrossRef]

9. Nguyen, V.T.B.; Nguyen, D.H.H.; Nguyen, H.H. Combination effects of calcium chloride and nano-chitosan on the postharvest quality of strawberry (Fragaria $x$ ananassa Duch.). Postharvest Biol. Technol. 2020, 162, 111103. [CrossRef]

10. Hou, Y.; Li, Z.; Zheng, Y.; Jin, P. Effects of $\mathrm{CaCl}_{2}$ Treatment Alleviates Chilling Injury of Loquat Fruit (Eribotrya japonica) by Modulating ROS Homeostasis. Foods 2021, 10, 1662. [CrossRef] 
11. Martín-Diana, A.B.; Rico, D.; Frías, J.M.; Barat, J.M.; Henehan, G.T.M.; Barry-Ryan, C. Calcium for extending the shelf life of fresh whole and minimally processed fruits and vegetables: A review. Trends Food Sci. Technol. 2007, 18, 210-218. [CrossRef]

12. Aghdam, M.S.; Dokhanieh, A.Y.; Hassanpour, H.; Rezapour Fard, J. Enhancement of antioxidant capacity of cornelian cherry (Cornus mas) fruit by postharvest calcium treatment. Sci. Hortic. 2013, 161, 160-164. [CrossRef]

13. Zhang, L.; Wang, J.-W.; Zhou, B.; Li, G.-D.; Liu, Y.-F.; Xia, X.-L.; Xiao, Z.G.; Fei, L.; Ji, S.-J. Calcium inhibited peel browning by regulating enzymes in membrane metabolism of 'Nanguo' pears during post-ripeness after refrigerated storage. Sci. Hortic. 2019, 244, 15-21. [CrossRef]

14. Zhang, M.; Liu, W.; Li, C.H.; Shao, T.T.; Jiang, X.; Zhao, H.Z.; Ai, W.T. Postharvest hot water dipping and hot water forced convection treatments alleviate chilling injury for zucchini fruit during cold storage. Sci. Hortic. 2019, 249, 219-227. [CrossRef]

15. Cao, X.; Zhang, F.; Zhao, D.; Wang, Z.; Zhu, D.; Li, J. Effects of Cold Shock Treatment on Freezing Characteristics of Grape. J. Chin. Inst. Food Sci. Technol. 2019, 19, 201-207. [CrossRef]

16. Duarte-Sierra, A.; Forney, C.F.; Michaud, D.; Angers, P.; Arul, J. Influence of hormetic heat treatment on quality and phytochemical compounds of broccoli florets during storage. Postharvest Biol. Technol. 2017, 128, 44-53. [CrossRef]

17. Yang, R.Q.; Hui, Q.R.; Gu, Z.X.; Zhou, Y.L.; Guo, L.P.; Shen, C.; Zhang, W.H. Effects of $\mathrm{CaCl}_{2}$ on the metabolism of glucosinolates and the formation of isothiocyanates as well as the antioxidant capacity of broccoli sprouts. J. Funct. Foods 2016, 24, 156-163. [CrossRef]

18. Grzegorzewska, M.; Kosson, R. The Influence of Postharvest Treatment and Type of Packaging on Quality and Storage Ability of Cauliflower (Brassica oleracea L. var. botrytis). J. Fruit Ornam. Plant Res. 2009, 71, 133-142. [CrossRef]

19. Wang, Y.; Xie, X.; Long, L.E. The effect of postharvest calcium application in hydro-cooling water on tissue calcium content, biochemical changes, and quality attributes of sweet cherry fruit. Food Chem. 2014, 160, 22-30. [CrossRef]

20. Supapvanich, S.; Arkajak, R.; Yalai, K. Maintenance of postharvest quality and bioactive compounds of fresh-cut sweet leaf bush (Sauropus androgynus L. Merr.) through hot $\mathrm{CaCl} 2$ dips. Int. J. Food Sci. Technol. 2012, 47, 2662-2670. [CrossRef]

21. Xue, J.X.; Wang, K.; Li, Z.Z.; Zhang, S.J.; Mu, B.Y.; Li, Z.H.; Huang, L.; Zhao, H.M.; Sun, H.X. Influences of post-harvest melatonin treatment on preservation quality and shelf life of fresh-cut cauliflower. Trans. Chin. Soc. Agric. Eng. 2021, 37, 273-283. [CrossRef]

22. Zhang, N.; Yan, R.X.; Guan, W.Q.; Wang, C. Effects of red light-emitting diode (LED) on the postharvest yellowing change of Broccoli. Spectrosc. Spectr. Anal. 2016, 36, 955-959. [CrossRef]

23. Yan, Z.C.; Shi, J.Y.; Gao, L.P.; Wang, Q.; Zuo, J.H. The combined treatment of broccoli florets with kojic acid and calcium chloride maintains post-harvest quality and inhibits off-odor production. Sci. Hortic. 2020, 262, 109019. [CrossRef]

24. Chen, X.L.; Zhang, L.H.; Yan, S.L.; Mei, X.; Shi, J.B.; Cai, S.; Sui, Y.; He, J.J. Effect of packaging materials on storage quality of fresh-cut broccoli. Food Sci. 2018, 39, 246-250. [CrossRef]

25. Xu, D.Y.; Liu, J.; Zuo, J.H.; Gao, L.; Wang, Q. Effect of Methyl Jasmonate Treatment on Quality of Postharvest Pepper Subjected Vibration during Transportation. Mod. Food Sci. Technol. 2018, 34, 70-76. [CrossRef]

26. Liu, Z.S.; Shi, J.Y.; Zuo, J.H.; Gao, L.P.; Wang, Q.; Meng, D.M. Effect of combined UV-C and red light emitting diode irradiation on storage quality of broccoli. Food Sci. 2020, 41, 238-245. [CrossRef]

27. Hazbavi, I.; Khoshtaghaza, M.H.; Mostaan, A.; Banakar, A. Effect of postharvest hot-water and heat treatment on quality of date palm (cv. Stamaran). J. Saudi Soc. Agric. Sci. 2015, 14, 153-159. [CrossRef]

28. Zhang, N.; Yang, Z.; Chen, A.G.; Zhao, S.S. Effects of intermittent heat treatment on sensory quality and antioxidant enzymes of cucumber. Sci. Hortic. 2014, 170, 39-44. [CrossRef]

29. Suzuki, Y.; Asoda, T.; Matsumoto, Y.; Terai, H.; Kato, M. Suppression of the expression of genes encoding ethylene biosynthetic enzymes in harvested broccoli with high temperature treatment. Postharvest Biol. Technol. 2005, 36, 265-271. [CrossRef]

30. Wang, L.; Wang, Q.; Liu, H.Z.; Liu, L.; Du, Y.; Zhang, J.S. Research Process on Peanut Processing Characteristics and Quality Evaluation. J. Chin. Cereals Oils Assoc. 2011, 26, 122-128.

31. Hu, X.Y.; Zhou, G.Y. Preservation Effect of Four Natural Preservatives on Cherry Tomatoes. Food Sci. 2012, 33, $287-292$.

32. Ribeiro, L.R.; Leonel, S.; Souza, J.M.A.; Garcia, E.L.; Leonel, M.; Monteiro, L.N.H.; Silva, M.D.; Ferreira, R.B. Improving the nutritional value and extending shelf life of red guava by adding calcium chloride. LWT Food Sci. Technol. 2020, 130, 109655. [CrossRef]

33. Naser, F.; Rabiei, V.; Razavi, F.; Khademi, O. Effect of calcium lactate in combination with hot water treatment on the nutritional quality of persimmon fruit during cold storage. Sci. Hortic. 2018, 233, 114-123. [CrossRef]

34. Aguayo, E.; Requejo-Jackman, C.; Stanley, R.; Woolf, A. Hot water treatment in combination with calcium ascorbate dips increases bioactive compounds and helps to maintain fresh-cut apple quality. Postharvest Biol. Technol. 2015, 110, 158-165. [CrossRef]

35. Wei, L.; Liu, C.; Zheng, H.; Zheng, L. Melatonin treatment affects the glucoraphanin-sulforaphane system in postharvest fresh-cut broccoli (Brassica oleracea L.). Food Chem. 2020, 307, 125562. [CrossRef]

36. Vale, A.P.; Santos, J.; Brito, N.V.; Marinho, C.; Amorim, V.; Rosa, E.; Oliveira, M.B.P.P. Effect of refrigerated storage on the bioactive compounds and microbial quality of Brassica oleraceae sprouts. Postharvest Biol. Technol. 2015, 109, 120-129. [CrossRef]

37. Reddy, Y.V.R.; Marcy, J.E.; Bratsch, A.D.; Williams, R.C.; Waterman, K.M. Effects of Packaging and Postharvest Treatments on the Shelf-Life Quality of Crown-Cut Broccoli. J. Food Qual. 2010, 33, 599-611. [CrossRef]

38. Tian, S.; Zhao, H.; Xue, X.; Zhao, Z.; Zhou, J. Effects of LOX and PG Enzymes in Chinese Jujube Fruit (Zizyphus Jujuba mill. cv. Dong) on Its Softening and Senescence. Food Sci. 2008, 29, 446-448. 
39. Zhang, P.; Chen, F.; Yang, H.; Li, L.; Gong, B.; Wang, L. Research advances on cell wall disassembly in fruit ripening and softening. Food Sci. Technol. 2010, 35, 62-66. [CrossRef]

40. Sheng, J.; Luo, Y.; Shen, L. Effects of PG and LOX on the softening and cell ultrastructure changes of postharvest tomato fruit. Acta Hortic. 2000, 27, 276-281.

41. Wu, J.; Wu, B.; Huang, S.; Chen, C.; Yan, L.; Xu, H.; Lin, J. Phospholipase D and Lipoxygenase of Young Loquat Fruits in Response to Low Temperature Stress. Plant Sci. J. 2015, 33, 203-209. [CrossRef]

42. Zhu, L.; Ling, J.; Shang, H.; Chen, S.; Cui, Y.; Kang, M. Factor analysis of the effects of controlled freezing-point storage in combination with 1-MCP treatment on quality of 'Yulu' juicy peaches during cold storage. J. Fruit Sci. 2016, 33, 1164-1172. [CrossRef]

43. Wu, X.; Gao, J.; Li, Y.; Wu, C. Development of A Safety Climate Scale for Geological Prospecting Projects in China. Int. J. Environ. Res. Public Health 2019, 16, 1082. [CrossRef] [PubMed]

44. Xue, J.; Huang, L.; Zhang, S.; Sun, H.; Gao, T. Study on the evaluation of carboxymethyl-chitosan concentration and temperature treatment on the quality of "Niuxin" persimmon during cold storage. J. Food Process. Preserv. 2020, 44, 14560. [CrossRef]

45. Olasege, B.S.; Zhang, S.; Zhao, Q.; Liu, D.; Sun, H.; Wang, Q.; Ma, P.; Pan, Y. Genetic parameter estimates for body conformation traits using composite index, principal component, and factor analysis. J. Dairy Sci. 2019, 102, 5219-5229. [CrossRef] [PubMed] 